Bull.Fac, Agric.,Cairo Univ.,63:212-216 (2012).

\title{
INFLUENCE OF SOME AGRICULTURAL PRACTICES ON THE INSECT INFESTATIONS OF SORGHUM IN FAYOUM.
}

(Received: 23. 2. 2012)

\author{
By \\ I. M. Sabra \\ Plant Protection Research Institute, Agricultural Research Center, Dokki, Giza, Egypt.
}

\begin{abstract}
A field study was carried out during 2010 and 2011 seasons on sorghum, Sorghum bicolor L. to evaluate the effect of some cultural practices (sowing date, plant distance and variety) on infestation with sorghum shoot fly, Atherigona soccata Rondani, corn stem borer, Sesamia cretica Led. and corn leaf aphid, Rhopalosiphum maidis (Fitch), in Fayoum, Egypt. The late sowing date (July 9) and the lowest plant distance $(15 \mathrm{~cm})$ showed the lowest infestation with the three pest species. All tested varieties or hybrids were insignificantly susceptible to the first two pest species, while was significant for the later one. A significantly negative correlation existed between the plant height of each variety or hybrid and infestation with $R$. maidis.
\end{abstract}

Key words: corn leaf aphid, corn stem borer, shoot fly and sorghum.

\section{INTRODUCTION}

Grain sorghum, Sorghum bicolor L. is a common cereal crop in Egypt, used for human consumption and as a food for poultry and livestock in the form of grain and forage. It is attacked by many insect pests from seedling until maturity. However, only three of them are considered as key pests. These pests are shoot fly, Atherigona soccata Rondani, stem borer Sesamia cretica Led. and corn leaf aphid, Rhopalosiphum maidis (Fitch).

A. soccata is a seedling maggot attacks the crop only in the early stage of growth and the infestation goes up to $80 \%$. The high yielding hybrids are more susceptible to the attack with this fly. The total loss in grain yield of shoot fly damage averaged $5-60 \%$ (Jotwani, 1983). The larvae crawl to the plant whorl and move downward between the folds of the young leaves until they reach the growing point. When they feed, they cut the growing tip and the result is drying of the central leaf called "dead heart." The economic injury level for A. soccata is 3.4 to $5.9 \%$ dead hearts, and $1 \%$ increase may result in a yield loss of 21 to $143 \mathrm{~kg}$ / ha (Puri 1983).

The larvae of stem borer, S. cretica bore into the stalk and kill the central shoot, causing a dead heart symptoms pre and during head emergence. Twenty percent dead hearts due to stem combine borer results in a significant reduction in grain yield (Taneja and Leuschner 1985).
Corn leaf aphids, Rhopalosiphum maidis is the dominant foliar-feeding insects on sorghum. Heavy aphid infestations on sorghum at the booting and heading stages seriously reduce both grain quality and yield.

The present work aimed to study the effect of some agricultural practices e.g., sowing date, plant distance and variety on the infestation by $A$. soccata, $S$. cretica and $R$. maidis on sorghum crop in Fayoum, Egypt, and also, threw some light on the relation between plant height and the infestation with $R$. maidis.

\section{MATERIALS AND METHODS}

Three agricultural practices were carried out in sorghum field to clarify their effects on the three insect pest species; A. soccata, S.cretica and $R$. maidis. The experiment was done in Fayoum region, during 2010 and 2011 seasons. The experimental area was $1 / 2$ feddan; divided into three equal plots; each represented one treatment.

\subsection{Planting date}

The plot of this treatment was divided into three equal subplots each was specialized for a date through four replicates. The first planting date was May $28^{\text {th }}$ while the others were on June $18^{\text {th }}$ and July $9^{\text {th }}$ of the two seasons. All the plots were seeded with Dorado sorghum variety.

\subsection{Plant distance}


In this treatment, each plot was divided as mentioned above, and planted on June $18^{\text {th }}$ with the same sorghum var. Each subplot was specified for one distance between hills; 15, 25 and $35 \mathrm{~cm}$ through four replicates.

\subsection{Variety}

Three sorghum varieties (Giza 15, Giza 113 and Dorado) and five hybrids (Shandawil 1, Shandawil 2, Shandawil 6, Hybrid 306 and Horus) were used in this treatment. The area, in this case, was divided into 8 equal subplots each was specialized for one of these varieties through four replicates. All these materials were seeded on June $18^{\text {th }}, 2010$ and 2011 seasons.

The distance between rows and that between hills were 50 and $20 \mathrm{~cm}$, respectively in all experiments except for that of the plant distance treatment. Also, all normal agricultural practices and no insecticides were applied.

Twenty eight days after emergence, a random sample of 50 plants from each replicate was directly inspected in the field; to record the numbers of dead hearts resulted from $A$. soccata infestation (Shekharappa and Bhuti 2007). Also, a similar sample was directly inspected in the field; 58 days after emergence, to record the numbers of dead hearts resulted from $S$. cretica infestation. As for $R$. maidis infestation, a similar sample of 50 plants was also carefully and directly detected in each replicate to record the numbers of the infested plants.

The plant height of each variety or hybrid was measured (58 days after emergence). The differences between the different means were evaluated using the ANOVA test. The simple correlation (r) value was calculated to define the relation between $R$. maidis infestation and sorghum varieties or hybrid heights.

\section{RESULTS AND DISCUSSION}

The obtained results are shown as follows

\subsection{Sowing date}

Data in Table (1) revealed that the sowing date affected the infestation with sorghum pests. Dead hearts caused by the shoot fly A. soccata was higher in the first sowing date (May, 28), in both seasons $(12.0-12.5 \%)$ than that in the late date (July 9) being $8.0-9.0 \%$. The plot of June 18 sowing date showed a moderate infestation; 11 and $9.5 \%$ in 2010 and 2011, respectively. The differences between infestation means were significant only in the second season. In this respect, Salman and Abdel-Moniem (2008) reported that, sorghum plants sowed on April, 20 or July, 9 showed a high percentage of $A$. soccata infestation than that sowed on May, 20. This result is in disagreement with Kumar et al. (2008) who reported that, early sowing of sorghum in India escape shoot fly damage.

The dead hearts caused by the stem borer $S$. cretica insignificantly differed in the three sowing dates in both seasons. The percentages were 7.0, 6.0 and $5.5 \%$ in the first season and 6.0, 4.5 and $4.0 \%$ in the second season for the three dates, respectively.

According to Al-Hasnawy (2009), the higher rate of infestation with the previous two pests in the first sowing date may be due to the high activity of emerged adults of the first generation so that, delaying the sowing date of sorghum to the end of July, significantly reduced the infestation of $S$. cretica and seedling dead hearts to $5.03 \%, 4.74 \%$, respectively.

Infestation percentages with the corn leaf aphid, $R$. maidis were nearly similar in both seasons. At the same time, they were relatively the highest in the second sowing date being 16.0 and $18.0 \%$ in 2010

Table (1): Effect of sowing dates on the insect infestations of sorghum during 2010 and 2011 seasons.

\begin{tabular}{|c|c|c|c|c|}
\hline \multirow{2}{*}{ Season } & \multirow{2}{*}{ Sowing date } & \multicolumn{2}{|c|}{ \% Dead hearts } & \multirow{2}{*}{ \% Aphids } \\
\cline { 2 - 5 } & & A. soccata & S. cretica & 14.0 \\
\hline \multirow{3}{*}{2010} & May 28 & 12.5 & 7.0 & 16.0 \\
\cline { 2 - 5 } & June 18 & 11.0 & 6.0 & 13.5 \\
\cline { 2 - 5 } & July 9 & 9.0 & 5.5 & 15.5 \\
\hline \multirow{3}{*}{2011} & May 28 & $12.0 \mathrm{a}$ & 6.0 & 18.0 \\
\cline { 2 - 5 } & June 18 & $9.5 \mathrm{ab}$ & 4.5 & 15.0 \\
\cline { 2 - 5 } & July 9 & $\mathbf{8 . 0} \mathrm{b}$ & 4.0 & \\
\hline
\end{tabular}

LSD $=2.61$ 
and 2011 seasons, respectively and that may be as a result of higher RH and temperature. In the USA, Archer et al. (1990) found that, the highest densities of $R$. maidis occurred in sorghum planted in May or June.

\subsection{Plant distance}

As shown in Table (2), the distance between plants, in both seasons significantly affected the infestation with $A$. soccata and $R$. maidis, while insignificant effect was recorded with $S$. cretica. The treatment of the lowest distance $(15 \mathrm{~cm})$, showed relatively the minimum dead heart percentages caused by $A$. soccata and $S$. cretica being 6 and 4\%, respectively in the two seasons. The treatment of the highest distance $(35 \mathrm{~cm})$, showed high dead heart percentages of 11.5 and $6 \%$ in 2010 season and 10.5 and $5.5 \%$ in 2011 season for the same insect pests, respectively. In the treatment of $25 \mathrm{~cm}$, the plants showing moderate dead heart percentages of 9 and $4.5 \%$ in 2010 season and 8.5 and $4 \%$ in 2011 season. Delobel (1982) in Kenya found that, low sorghum density showed a high infestation of $A$. soccata.
$15.5,13.0$ and $10.5 \%$ in 2011 season opposite 15 , 25 and $35 \mathrm{~cm}$ distances, respectively. This behavior may be as a result of the high humidity found in the crowded plants and easy insect transmission in this case.

\subsection{Variety}

Data given in Table (3) showed that, the studied varieties and hybrids of sorghum had nearly a similar susceptibility to the infestation with the three aforementioned pests throughout the two seasons. No significant differences were detected between the levels of dead hearts caused by $A$. soccata and $S$. cretica. In the case of $R$. maidis these differences were statistically significant in both seasons.

Regardless of season, all tested varieties and hybrids slightly differed in their ability to be infested with A. soccata, $5.5-9.0 \%$ dead hearts. Also, $S$. cretica showed a similar result, since the percentage of dead hearts ranged $4-7$ and $3.5-6.5$ $\%$ in 2010 and 2011 seasons, respectively. These results are in agreement with Dhillon et al. (2006) and Berg et al. (2005) who stated that sorghum varieties had low to moderate levels of resistance to

Table (2): Effect of plant densities on insect infestations of sorghum during 2010 and 2011 seasons.

\begin{tabular}{|c|c|c|c|c|}
\hline \multirow{3}{*}{ Season } & \multirow{2}{*}{ Plant distance $(\mathrm{cm})$} & \multicolumn{2}{|c|}{ \% Dead hearts } & \multirow{2}{*}{ \% Aphids } \\
\cline { 2 - 5 } & & A. soccata & S. cretica & \\
\hline \multirow{3}{*}{2010} & 15 & $6.0 \mathrm{~b}$ & 4.0 & $18.5 \mathrm{a}$ \\
\cline { 2 - 5 } & 25 & $9.0 \mathrm{ab}$ & 4.5 & $16.0 \mathrm{ab}$ \\
\cline { 2 - 5 } & 35 & $11.5 \mathrm{a}$ & 6.0 & $13.5 \mathrm{~b}$ \\
\cline { 2 - 5 } LSD & & 3.65 & - & 3.61 \\
\hline \multirow{3}{*}{2011} & 15 & $6.0 \mathrm{~b}$ & 4.0 & $15.5 \mathrm{a}$ \\
\cline { 2 - 5 } & 25 & $8.5 \mathrm{ab}$ & 4.0 & $13.0 \mathrm{ab}$ \\
\hline \multirow{2}{*}{ LSD } & 35 & $10.5 \mathrm{a}$ & 5.5 & $10.5 \mathrm{~b}$ \\
\hline
\end{tabular}

The obtained results revealed that keeping the high density of plants, by delaying plant thinning at a time when plants passed the susceptible stage (plant height exceeds $22 \mathrm{~cm}$ ) and remove the infested plant was useful in controlling A. soccata. On contrary of the previous results, $R$. maidis infestation increased with reducing the densities of plants; $18.5,16.0$ and $13.5 \%$ in 2010 season, and the stem borer and shoot fly.

The results showed also that, these varieties and hybrids had different degrees of infestation with the corn leaf aphid $R$. maidis. While Dorado was the highest infested variety during the two seasons (19.0 and $14.5 \%$ ), Giza 15 and 113 had the lowest infestation, $4.5 \& 5.0$ in the first season and $2.5 \&$ $3.0 \%$ in the second one. Shandawil 1, Shandawil 2, 
Table (3): Susceptibility of sorghum varieties to insect infestations and the effect of their height on aphid infestation during 2010 and 2011 seasons.

\begin{tabular}{|c|c|c|c|c|c|}
\hline \multirow{2}{*}{ Season } & \multirow{2}{*}{$\begin{array}{l}\text { Variety \& } \\
\text { hybrid }\end{array}$} & \multicolumn{2}{|c|}{ Dead hearts/100 plants } & \multirow{2}{*}{ \% Aphids } & \multirow{2}{*}{$\begin{array}{c}\text { Plant height } \\
\text { (cm) }\end{array}$} \\
\hline & & A.soccata & S. cretica & & \\
\hline \multirow{8}{*}{2010} & Dorado & 9.0 & 7.0 & 19.0a & 105 \\
\hline & Giza 15 & 9.0 & 5.5 & $4.5 \mathrm{c}$ & 335 \\
\hline & Giza 113 & 8.0 & 5.5 & $5.0 \mathrm{c}$ & 300 \\
\hline & Shandawil 1 & 7.5 & 6.5 & $11.5 b$ & 140 \\
\hline & Shandawil 2 & 7.0 & 7.0 & $11.0 b$ & 144 \\
\hline & Shandawil 6 & 7.5 & 4.5 & $6.0 \mathrm{c}$ & 160 \\
\hline & Hybrid 306 & 7.0 & 5.5 & $11.0 b$ & 145 \\
\hline & Horus & 5.5 & 4.0 & $7.5 \mathrm{c}$ & 155 \\
\hline \multirow{8}{*}{2011} & Dorado & 9.0 & 6.5 & $14.5 \mathrm{a}$ & 100 \\
\hline & Giza 15 & 8.0 & 5.5 & $2.5 \mathrm{~b}$ & 340 \\
\hline & Giza 113 & 6.5 & 6.5 & $3.0 \mathrm{~b}$ & 295 \\
\hline & Shandawil 1 & 7.0 & 4.5 & $11.5 \mathrm{a}$ & 138 \\
\hline & Shandawil 2 & 6.5 & 4.0 & $11.0 \mathrm{a}$ & 138 \\
\hline & Shandawil 6 & 9.5 & 4.0 & $10.5 \mathrm{a}$ & 155 \\
\hline & Hybrid 306 & 8.5 & 5.0 & $11.5 \mathrm{a}$ & 133 \\
\hline & Horus & 6.5 & 3.5 & $6.0 \mathrm{~b}$ & 158 \\
\hline
\end{tabular}

LSD $=3.48,(r)=-0.74 *$ in 2010 season, $\mathrm{LSD}=4.37,(r)=-0.92 *$ in 2011 season.

Shandawil 6 and hybrids 306 showed relatively higher infestations in both seasons. Horus hybrid was moderately infested with aphids (7.5 \& 6\%) during both seasons. In Iraq, Al-Hasnawy (2009) found significant differences between sorghum varieties to aphid infestation.

\subsection{Plant height}

Data presented in Table (3) revealed that, the varying heights of the different sorghum hybrids or varieties were significantly negative correlated with the infestation of aphids in both seasons. Values of (r) were -0.74 and -0.92 in 2010 and 2011 seasons, respectively. Generally, the tall varieties such as Giza 15 and Giza 113 were the least susceptible to the infestation when compared to the short varieties or hybrids as Dorado, Shandawil 1, Shandawil 2 and Hybrid 306. The medium height hybrids as Shandawil 6 and Horus showed also a moderate infestation with aphids.

\section{REFERENCE}

Al-Hasnawy M. M. (2009). Field studies on the abundance of insect species of sorghum ((Sorghum bicolor (L.) Moench)) and some techniques to control the key pest. M. Sc. Thesis, College of Agric. Baghdad Univ.

Archer T. L., Losada J. C. and Bynum E. D. (1990). Influence of planting date on abundance of foliage-feeding insects and mites associated with sorghum. J. Agric. Entomol., 7 (3) : 221232.

Berg J., Bronkhorst L., Mgonja M. and Obilana A. B. (2005). Resistance of sorghum varieties to the shoot fly, Atherigona soccata Rondani (Diptera: Muscidae) in Southern Africa. International J. Pest Management, 51 (1): 1-5.

Delobel A. (1982). Effects of sorghum density on oviposition and survival of the sorghum shoot fly, Atherigona soccata. Entmol. Exp. Appl., 
$31: 170-174$.

Dhillon M.K., Sharma H.C., Reddy B.V.S., Singh Ram and Naresh J.S. (2006). Inheritance of resistance to sorghum shoot fly, Atherigona soccata. Crop Science Society of America. http://www. highbeam. com/doc/1G1146125276. Html.

Jotwani M.G. (1983). Losses due to shoot fly in high yielding sorghum cultivars. Proceedings, Crop losses due to insect pests. Entomological Society of India: 213-220.

Kumar A. A., Reddy B., Sharma H.C. and Ramaiah B. (2008). Shoot fly (Atherigona soccata) resistance in improved grain sorghum hybrids. J. Sat Agric. Research, $6: 1$ - 4.

Puri S. N. (1983). A review of twenty five years of entomological research on sorghum in Maharashtra. Res. Bull. Marathwada Agri.
Univ., 7 (1) : 1-22.

Salman A.M. and Abdel-Moniem A.S.H. (2008). Effect of planting dates and maize hybrids on the infestation with sorghum shoot fly, Atherigona soccata Rondani and its effect on the yield. Archive of Phytopathology and Plant Protection, 41 : 349-359.

Shekharappa and Bhuti S.G. (2007). Integrated management of sorghum shoot fly, Atherigona soccata Rondani. Karnataka J. Agric. Sci., 20 (3) :535 - 536.

Taneja S.L., and Leuschner K. (1985). Methods of rearing, infestation, and evaluation for Chilo partellus resistance in sorghum. Proc. Int. Entomol. Workshop, 15-21 July 1984, Texas A \& M University, College Station, Texas, USA. 175-188.

\section{تأثير بعض العمليات الزراعية على إصابة محصول الأرة الرفيعة بالآفات الحشرية بمحافظة الفيوم. \\ ابراهيم مخيمر صبرة

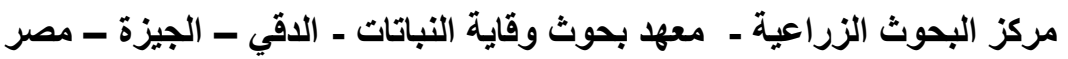

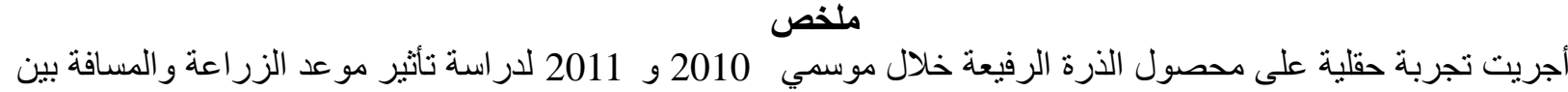

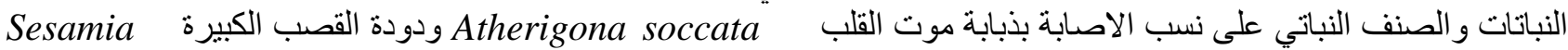

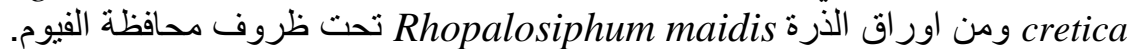

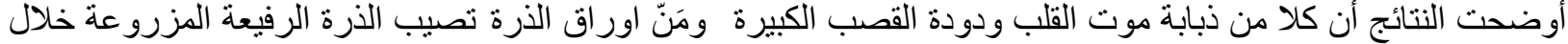

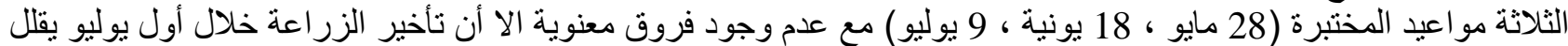

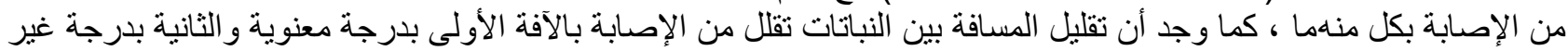

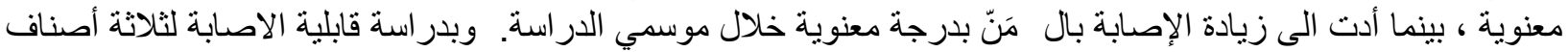

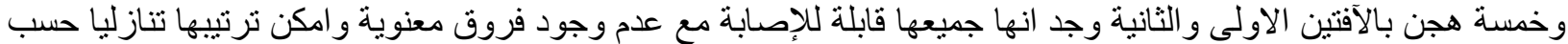

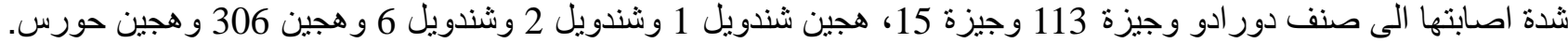

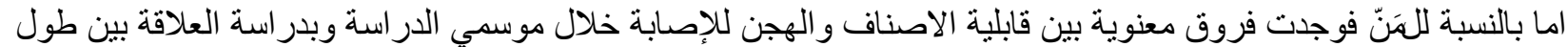

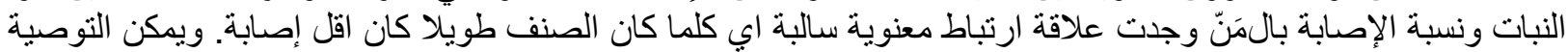

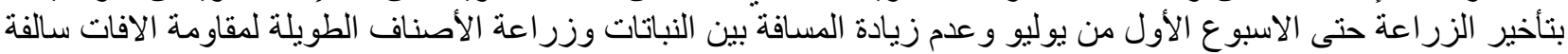
المجلة العلمية لكلية الزراعة - جامعة القاهرة - المجلا (63) العدد الثانى (ابريل 2012):212-212. 